\title{
Adrenal Insufficiency in Sepsis ${ }^{\star}$
}

\author{
Insuficiência Adrenal na Sepse
}

\author{
Andrea Polito ${ }^{1}$, Jérôme Aboab ${ }^{1}$, Djillali Annane, $P h D^{1}$
}

\section{RESUMO}

JUSTIFICATIVA E OBJETIVOS: Corticosteróides foram introduzidos no tratamento das infecções graves há várias décadas, Diversos estudos aleatórios e controlados com resultados negativos utilizando corticóides em doses elevadas por curto período na sepse ou SARA trouxeram questionamentos acerca da eficácia deste tratamento. Recentemente, um elo entre a inflamação sistêmica e a insuficiência adrenal foi estabelecida. Este achado renovou o interesse na reposição de baixas doses de corticóides por períodos mais longos. O objetivo deste artigo é revisar o papel dos corticosteróides na resposta do hospedeiro ao stress e atualizar o leitor com indicações novas e validadas de reposição de corticosteróides.

CONTEÚDO: Extensa revisão da fisiologia adrenal e das alterações fisiopatológicas e suas implicações clínicas em pacientes críticos.

CONCLUSÕES: Na vigência de sepse, instabilidade hemodinâmica e perpetuação da resposta inflamatória podem resultar de insuficiência adrenal (IA). Desta forma teste de estimulação com ACTH devem ser realizados precocemente para identificação de IA. À realização do teste deve seguir a reposição de $50 \mathrm{mg}$ de hidrocortisona em bolus e a cada 6 horas associado a

\section{Faltou a titulação}

*From Service de Reanimation Medicale, Hopital Raymond Poincare, Assistance Publique-Hopitaux de Paris, Faculte de Medecine Paris lle de France Ouest, Universite de Versailles Saint-Quentin en Yvelines, Garches, France

Submitted to December, 22, 2005

Accepted to January, 27, 2006

Correspondence to:

Service de Reanimation, Hospital Raymond Poincaré (AP-HP)

University of Versailles

SQ, 104 Boulevard Raymond Poincaré,

Garches 92380.

Phone: 33147107787

Fax: 33147107783

E-mail: Djillali.Annane@rpc.ap.hp.fr
$50 \mu \mathrm{g}$ de fludrocortisona uma vez ao dia. Quando os resultados do teste com ACTH encontrarem-se disponíveis, a terapia deverá ser continuada por sete dias nos não-respondedores e descontinuada nos respondedores. A decisão acerca do tratamento de respondedores ao ACTH com cortisol > $34 \mu \mathrm{g} / \mathrm{dL}$ com potencial resistência periférica ao cortisol deve ser avaliada em futuros ensaios clínicos.

Unitermos: ACTH, cortisol, disfunção orgânica múltipla, insuficiência adrenal, sepse

\section{SUMMARY}

BACKGROUND AND OBJECTIVES: Corticosteroids were introduced in the treatment of severe infection as early as in the nineteen forties. Several "negative" randomized controlled trials of high-dose of glucocorticoids given for a short period of time in the early course of severe sepsis or acute respiratory distress syndrome raised serious doubts on the benefit of this treatment. Recently, a link between septic shock and adrenal insufficiency, or systemic inflammation induced glucocorticoids receptor resistance had been established. This finding prompted renewed interest of a replacement therapy with low doses of corticosteroids during longer periods. The goal of this article is to review the key role of corticosteroids in the host response to stress and will update the reader with the new validated indications of corticosteroids treatment in the ICU.

CONTENTS: Extensive review of the adrenal physiology and its pathophysiological derangements and clinical implications in critically ill patients.

CONCLUSIONS: During sepsis, hemodynamic instability and perpetuation of inflammatory state may result from adrenal insufficiency (Al). Thus, an ACTH test should be performed as soon as possible to identify non overt Al. It should be immediately followed by a replacement therapy with iv bolus of $50 \mathrm{mg}$ of hydrocortisone every 6 hours combined to $50 \mu \mathrm{g}$ of fludrocortisone once daily. When the results of the ACTH test are available, treatment should be continued for 7 days in the non responders to ACTH and withdraw in the 
responders. Whether responders to ACTH with high baseline cortisol levels ( $>34 \mu \mathrm{g} / \mathrm{dL}$ ) have tissue resistance to cortisol and also should receive exogenous hormones remains to be evaluated in clinical trials.

Key Words: ACTH, adrenal insufficiency, cortisol, multiple organ dysfunction syndrome, sepsis

\section{INTRODUCTION}

In the beginning of the twentieth century, observations of apoplectic adrenal glands in fatal meningococcemia underlined their key role in host defense against infection. Thirty years after, cortisone was discovered and rapidly proven to have numerous and diversified physiological functions in the host response to stress. Corticosteroids were introduced in the treatment of severe infection as early as in the nineteen forties. Several "negative" randomized controlled trials of high-dose of glucocorticoids given for a short period of time in the early course of severe sepsis or acute respiratory distress syndrome raised serious doubts on the benefit of this treatment. Recently, a link between septic shock and adrenal insufficiency, or systemic inflammation induced glucocorticoids receptor resistance had been established. This finding prompted renewed interest of a replacement therapy with low doses of corticosteroids during longer periods. We will review the key role of corticosteroids in the host response to stress and will update the reader with the new validated indications of corticosteroids treatment in the ICU.

\section{REGULATION AND PRODUCTION OF CORTICOSTEROIDS}

\section{At Rest}

The adrenal gland is made of two functional units, the medulla which produces catecholamines and cortex composed of three zones: zone glomerulosa, superficially located, producing mineralocorticoids (aldosterone and corticosterone), zone reticularis deeper sited producing weak androgens and zone fasciculate producing corticosteroids (cortisol and corticosteron) (Figure1).

Cortisol, the main corticosteroid, is a steroid hormone of 19 carbon atoms derived from cholesterol by an enzyme of P450 cytochrome complex. Cortisol circulates in plasma either in its free and active form (which accounts only for $5 \%$ to $10 \%$ of total cortisol) or in its inactive form, reversibly bound to proteins. The two main binding proteins are the cortisol-binding globulin

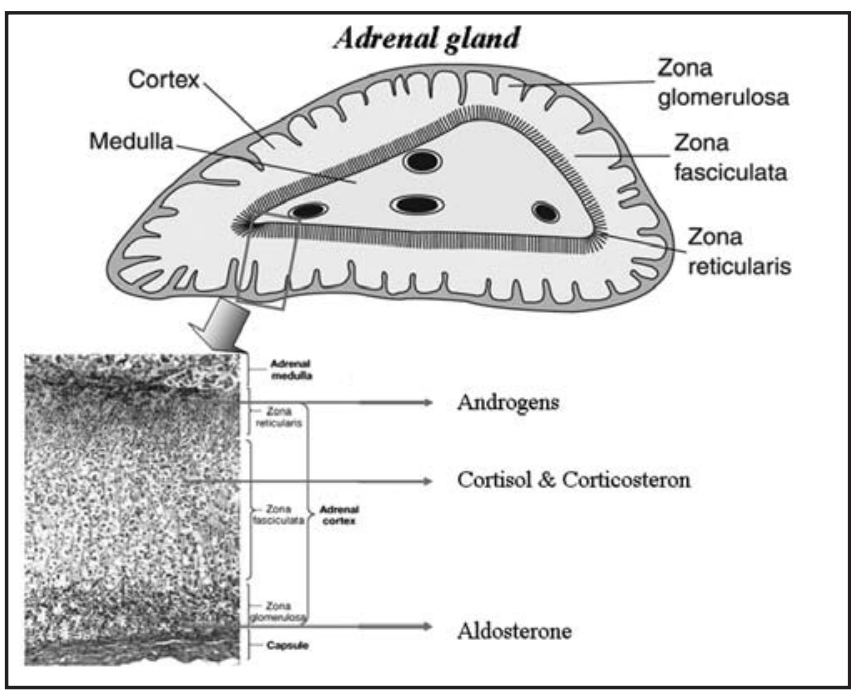

Figure 1 - Main Hormones Secreted by Cortex of Adrenal Gland

(CBG) and albumin 1.

Production of corticosteroids is regulated by the hypothalamic-pituitary-adrenal (HPA) axis. Cortisol production and secretion is stimulated mainly by the adrenocorticotrophic hormone (ACTH). This is a 39 amino acids peptide produced in the anterior pituitary. It is obtained after the cleavage of a large precursor, the pro-opiomelanocortin, which also liberates other peptides ( $\beta$-endorphin, lipotropin, melanocyte-stimulating hormone). In the short term, ACTH stimulates cortisol production and secretion even if cortisol storage in adrenal glands being low; in the longer term, ACTH also stimulates the synthesis of enzymes that are involved in cortisol production, as well as their cofactors and adrenal receptors for low-density lipoprotein cholesterol. ACTH also stimulates the production of adrenal androgens and, to a lesser extent, mineralocorticoids ${ }^{1}$.

The half-life of ACTH is short and cortisol concentration in adrenal veins rises only a few minutes after ACTH secretion ${ }^{2}$. Secretion of ACTH is regulated by several factors among which the corticotrophin-releasing hormone $(\mathrm{CRH})$ and arginine vasopressin (AVP), which are both secreted by the hypothalamus. AVP stimulates ACTH secretion only weakly but it strongly promotes $\mathrm{CRH}$ action. Catecholamines, angiotensin II, serotonin and vasoactive intestinal peptide are also known stimulators of ACTH secretion. Finally, some inflammatory cytokines influence ACTH secretion, exerting either a stimulatory action (IL-1, IL-2, IL-6, tumour necrosis factor TNF- $\alpha$ ) or an inhibitory one (transforming growth factor- $\beta)^{2-4}$.

$\mathrm{CRH}$ is a 41 -amino-acid peptide secreted by the hy- 
pothalamus. Liberated in the hypothalamic-pituitary portal system, it stimulates the production and the secretion of pro-opiomelanocortin. Adrenergic agonists (noradrenaline) and serotonin stimulate its production whereas substance $P$, opioids and $\gamma$-aminobutyric acid inhibit it. Inflammation cytokines (IL-1, IL-2, IL-6, TNF$\alpha)$ also influence production of $\mathrm{CRH}^{2-5}$.

Finally, corticosteroids exert a negative feedback on the HPA axis, inhibiting ACTH production as well as pro-opiomelanocortin gene transcription, and $\mathrm{CRH}$ and AVP production. Secretion of the HPA axis hormones (ACTH, CRH and AVP) follows a pulsatile course with a circadian rhythm. The amplitude of the secretory pulses varies throughout the day and is greatest in the morning between 6 and $8 \mathrm{AM}$, rapidly decreasing until noon and decreasing more slowly until midnight ${ }^{1}$.

However, the brain and the pituitary, which regulate the production of corticosteroid secretion through negative feedback by sensing time-integrated tissue exposure to corticosteroids, are also targets of corticosteroids. Thus, any generalized change in the corticosteroid signaling system will be followed by corrective, compensatory, and generally protective changes in the activity of the HPA axis by adjusting target tissue effects to optimal levels ${ }^{2,6}$. Absence of complete compensation - be it excessive or deficient - could result in chronically altered homeostasis or allostasis and target tissue pathology, as occurs in chronically stressed or depressed individuals who have mild but persistent hyper- or hyposecretion of cortisol ${ }^{2,7}$. The suprahypothalamic, hypothalamic, and pituitary corticosteroidsensing network, however, differs from the networks of corticosteroid signaling systems in the arousal, associative, reward, metabolic, cardiovascular, and immune systems. Any change in one or more molecules that participate in the corticosteroid signaling system could potentially produce a discrepancy in the sensitivity of target tissues to corticosteroids and result in pathology ${ }^{2,8}$. For these reasons any polymorphism or mutation of GR gene may affect corticosteroid signaling pathway and being responsible for different diseases according to corticosteroid tissue sensitivity that may be augmented (hypertension, diabetes mellitus II, visceral obesity-related insulin resistance) $)^{2,6,7}$ or decreased (asthma, ARDS) ${ }^{2,7}$. Moreover, tissue sensitivity to corticosteroids is affected by interactions of the host with viruses, such as human immunodeficiency viruses type 1, which increases corticosteroid sensitivity of host tissues, and the adenovirus, which decreases $i^{19,10}$.

\section{DURING STRESS}

Corticosteroids are the main mediators of the stress response. During a stressing event it appears an immediate increment of ACTH secretion rapidly followed by increase in cortisol level ${ }^{11}$. Moreover CBG level decreases and subsequently free cortisol rises ${ }^{12}$. Pro-inflammatory cytokines play a crucial role in the activation of HPA axis ${ }^{13}$. These events are associated with a loss of the circadian rhythm of cortisol secretion secondary to an increase in $\mathrm{CRH}$ and $\mathrm{ACTH}$ production stimulated by inflammatory cytokines, vagal stimulation and reduction in cortisol-negative feedback ${ }^{11,14}$. All the changes during stress have the purpose to maintain homeostasis. Metabolic effects, especially hyperglycemia allow the redistribution of glucose toward insulin-dependant cells. Cardiovascular effects of corticosteroids aim to maintain normal vascular reactivity and almost all the component of the inflammatory cascade are prevented by cortisol. However, the ability of the HPA axis to cortisol sustained inflammatory insult like one resulting from severe infection, is likely a determinant of the progression from sepsis to septic shock and death.

About "normal" concentration of circulating cortisol in critical illness is not clear what the right value is. Has been proposed to consider the range from 15 to $20 \mu \mathrm{g} /$ $\mathrm{dL}$ as norma| ${ }^{5,15-17}$. Even if is controversial, the higher the cortisol level at admission on ICU, the higher the mortality rate [18]. Cortisol serum level seems an independent predictive factor for outcome and likely the severity of stress. However, it is more essential to determine the ability of the endocrine system to respond to sustained stress and thus, dynamic testing of adrenal function is of paramount importance. The most convenient test in ICU is the standard ACTH stimulation test. Normally a rise of circulating cortisol concentration of 9 $\mu \mathrm{g} / \mathrm{dL}$ or more is considered as a normal response ${ }^{19,20}$.

\section{MECHANISM OF ADRENAL INSUFFICIENCY IN SEPSIS}

The recognition of various disorders that cause adrenal insufficiency (Al), either at a clinical or molecular level, often has implications for the management of the patient. Recent molecular-genetic analysis for the disorder that causes Al gives valuable insights into adrenal organogenesis, regulation of steroid hormone biosynthesis, and the developmental and reproductive endocrinology.

During sepsis numerous factors may interfere with HPA 
axis function, e.g. pre-existing defect of adrenal or pituitary gland, inflammation of the endocrine tissues, anatomic damage of the gland, drugs inhibiting enzymatic step of cortisol synthesis (e.g. etomidate, ketoconazole), or increasing cortisol metabolism (phenytoin, phenobarbital) $)^{11,21}$.

The various etiologies of $\mathrm{Al}$ can be subgrouped into three categories: 1) impaired steroidogenesis, 2) adrenal dysgenesis/hypoplasia, and 3) adrenal destruction. Al develops only when a large part of the function of the adrenal gland is lost. Primary Al is caused by processes that damage the adrenal glands or by drugs that block cortisol synthesis. In contrast, secondary Al results from processes that reduce the secretion of ACTH by the pituitary gland due to a pituitary or hypothalamic pathology. More often in sepsis necrosis or hemorrhage of the hypothalamus or of the pituitary gland have been reported, as a result of prolonged hypotension or severe coagulation disorders ${ }^{22}$. Sepsis may also exacerbate chronic known or latent secondary $\mathrm{Al}$, which may due to hypothalamic or pituitary tumors, chronic inflammation or congenital ACTH deficiency. Secondary Al may follow drug therapy. Previous treatment with corticosteroids reduces secretion of $\mathrm{CRH}$ and $\mathrm{ACTH}$, resulting in slow onset of secondary Al. This suppression depends on duration of pre-treatment and on the type of corticosteroid used. Hydrocortisone is the least suppressive agent and dexamethasone the most ${ }^{23}$. The opioids reduce cortisol serum level probably by acting at the level of the hypothalamus ${ }^{24}$. Infection diseases, viral and fungal especially, may cause chronic primary $\mathrm{Al}$, particularly in immunosuppressed patients, like HIV patients ${ }^{5}$. Certain drugs may decrease steroidogenesis, like etomidate. This effect persists as long as 24 hours after a single dose in critically ill patients ${ }^{25,26}$. In addition cyclosporine ${ }^{27}$, clarithromycin ${ }^{28}$ accelerate cortisol metabolism.

\section{DIAGNOSIS OF AI IN SEPSIS}

Usually, the adrenal crisis is characterized by fever, nausea, vomiting, abdominal pain, impaired consciousness, hypotension which is refractory to fluids and vasopressor therapy, hypoglycemia, hyponatremia and hypereosinophilia. Unfortunately, these symptoms are very common during severe sepsis and thus they lack specificity to help in the decision making process. Thereafter, whenever Al is suspected endocrine tests are mandatory.

Nonstimulated Serum Cortisol: This test measure plasma ACTH and serum cortisol in the morning, when the latter peaks. The test requires that cortisol circadian rhythm is normal. A serum cortisol level of less than $3 \mu \mathrm{g} / \mathrm{dL}$ probably indicates Al [29]. In the latter case, plasma ACTH level will distinguish between primary and secondary Al. In primary Al, the ACTH level is almost invariably more than $100 \mathrm{pg} / \mathrm{mL}$, while in secondary Al, plasma ACTH can be either low or inappropriately normal. In patients with severe stress, like sepsis, serum cortisol level should be more than $18 \mu \mathrm{g} / \mathrm{dL}$ at any time. One exception may the patient with severe hypoproteinemia from whom total cortisol levels are no more accurate ${ }^{30}$. However, in sepsis, high total cortisol levels may result from impaired cortisol clearance or tissue resistance and thus dynamic tests of adrenal function are essential t rule out Al.

Insulin-Induced Hypoglycemia (Insulin Tolerance Test, ITT). This measures the patient's cortisol response to hypoglycemia induced by the intravenous administration of insulin. This test is often considered as the gold standard because it assesses the ability of the entire HPA axis to respond to the stressful situation of hypoglycemia. Following insulin $(0.1 \mathrm{IU} / \mathrm{kg})$ administration, blood is drawn during symptomatic hypoglycemia (glucose should decrease to less than $40 \mathrm{mg} / \mathrm{dL}$ $[<2.22 \mathrm{mmol} / \mathrm{L}])$. In obese patients with insulin resistance, the usual dose of insulin should be increased to $0.15 \mathrm{IU} / \mathrm{kg}^{31}$. A serum peak cortisol of more than 18 $\mu \mathrm{g} / \mathrm{dL}$ is considered normal. ITT has some limitations in terms of reproducibility and clear cut-off levels ${ }^{32,33}$ and is contraindicated in patients with unstable hemodynamic status. In addition, peripheral insulin resistance that characterizes sepsis, made this test less accurate in this context.

Metyrapone Test. The metyrapone test measures the ability of the HPA axis to respond to an acute reduction in serum cortisol levels. Metyrapone inhibits 11hydroxylase, the enzyme involved in the last step of cortisol synthesis. This inhibition causes a decrease in cortisol that results in a compensatory increase in ACTH and in the cortisol precursor, 11-deoxycortisol. The administration of metyrapone $(30 \mathrm{mg} / \mathrm{kg}$; maximal dose, $3000 \mathrm{mg}$ ) occurs at midnight, and blood is drawn the following morning at $8 \mathrm{AM}$ for cortisol and 11-deoxycortisol ${ }^{34}$ in response to metyrapone, serum cortisol level should decrease to less than $5 \mu \mathrm{g} / \mathrm{dL}$, and 11-deoxycortisol should increase to more than $7 \mu \mathrm{g} / \mathrm{dL}$. This test can be effectuated in healthy patients and it may be performed in ICU patients only when enteral nutrition is available. It should be administered very 
cautiously as it may cause adrenal crisis.

CRH Stimulation Test. The CRH stimulation test measures the ability of the pituitary gland to secrete ACTH in response to $\mathrm{CRH}$. Ovine $\mathrm{CRH}(1 \mu \mathrm{g} / \mathrm{dL})$ is injected intravenously, and cortisol is measured after 15,30 , and 60 minutes. The test has been proposed as a way to differentiate secondary (pituitary disease) from tertiary (hypothalamic disease) Al. However, the accuracy of this test remains very controversial ${ }^{35}$.

ACTH Stimulation Test. The ACTH stimulation test is based on the inability of a diseased adrenal gland to respond acutely to the injection of ACTH by secreting cortisol. ACTH is injected intravenously (or intramuscularly), and serum cortisol levels are measured at 30 or 60 minutes. In critical illness, cortisol levels less than 15 $\mu \mathrm{g} / \mathrm{dL}$ or a cortisol increment of $9 \mu \mathrm{g} / \mathrm{dL}$ or less indicates $\mathrm{Al}$ and identifies patients that require a replacement therapy ${ }^{16,17,36}$. Finally, an increase in cortisol level more than $9 \mu \mathrm{g} / \mathrm{dL}$ with the basal level above $34 \mu \mathrm{g} / \mathrm{dL}$, suggests tissue resistance to corticosteroid.

As plasma ACTH levels following a bolus of $250 \mu \mathrm{g}$ of ACTH exceed by several times the levels achieved during major surgery, it has been suggested that the "High Dose" that may miss "mild" secondary $\mathrm{Al}^{37}$. Subsequently, the $1 \mu \mathrm{g} \mathrm{ACTH}$ test (LDST) was introduced as a more sensitive test ${ }^{38}$. However, $1 \mu \mathrm{g}$ of ACTH induces supramaximal stimulation of the adrenals for only 30 min and may not appropriately evaluate the capacity of the adrenal glands to maintain maximal cortisol production in response to a major ongoing stress like sepsis. In addition, interpretation of the results of the $1 \mu \mathrm{g}$ dose ACTH testing is very dependent on determination of the lower limit of normality.

Given the uncertainty surrounding the reliability of the LDST in general, and the fact that in septic shock the benefit of cortisol replacement therapy has been shown only in nonresponders to the "High Dose" test, we strongly recommend using the high dose ACTH test.

\section{MOLECULAR MECHANISM OF ACTION OF CORTICOSTEROIDS}

The human corticosteroid receptor (GR) is located in chromosome 5 and is responsible of the production of the subunit $\alpha$ and $\beta$. The classic receptor has three major distinct functional domains-the $\mathrm{N}$-terminal or immunogenic domain, the DNA binding domain (DBD), and the ligand-binding domain (LBD). In its unbound state, GR $\alpha$ is located primarily in the cytoplasm as part of a hetero-oligomeric complex that contains heat shock proteins (HSPs) 90, 70, 50, and 20 and, possibly, other proteins as well ${ }^{7}$. After binding to an agonist ligand, GR undergoes conformational changes, dissociates from the HSPs and other chaperon proteins, and translocates into the nucleus through a nuclear pore as a monomer or dimer by means of an active adenosine triphosphate-dependent process mediated by its nuclear localization signals NL1 and $\mathrm{NL} 2{ }^{~}$. Once in the nucleus, ligand-activated GR $\alpha$ dimers interact directly with specific DNA sequences in the promoter regions of target genes (the corticosteroid response elements, GREs). Ligand-activated GR $\alpha$ monomers, interact with other transcription factors also, at the cytoplasm level [e.g. nuclear factor $\kappa \mathrm{B}(\mathrm{NF}-\kappa \mathrm{B})$, activating protein 1 (AP-1), p53, CRE-binding protein (CREB), signal transducer and activator of transcription 5 (STAT5)] through protein-protein interactions, indirectly influencing the activity of the latter on their own target genes [7]. GR contains two transactivation domains (activation function 1, AF-1 and $A F-2$ ) at its N-terminal and $L B D$, respectively. GR interacts through $A F-1$ and $A F-2$ with various protein complexes, including the nuclear receptor coactivator complexes (p160, p300/CREB-binding protein, $\mathrm{CBP}$, and $\mathrm{p} 300 / \mathrm{CBP}$-associated factor, $\mathrm{p} / \mathrm{CAF}$ ) and other factors that can alter the transcription rates of corticosteroid-responsive genes ${ }^{7}$ (Figure 2). The GR isoform $\beta$ does not itself bind corticosteroids, but ra-

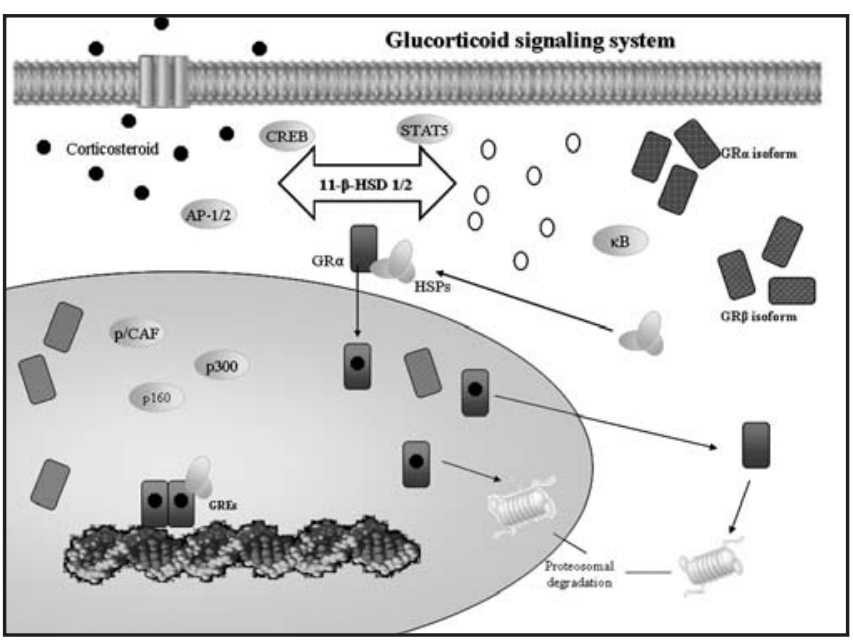

Figure 2 - Intracellular GR Activation.11ß-HDS1/2 Regulates the Conversion of Inactive Cortisone (white circle) to the Active GR ligand Cortisol (black circles). Cortisol binds to the Citoplasmic HPS (heat protein shock)-bound GR and translocate into the nucleus. There interacts with DNA target Sequences and Glucocorticoid Sequences and Glucocorticoid Response Elements (GREs). Alternatively, GR Monomers Interact with and after the Activity of a Host of Transcription Factors such a NF- $\mathrm{KB}$, AP1 and STAT5. 
ther exerts dominant negative effects on GR $\alpha$ through several mechanisms, such as heterodimerization and competition with GR $\alpha$ for GREs or transcriptional nuclear receptor coactivators ${ }^{6,7,39-41}$. GR $\alpha$ translational isoforms are differentially expressed in various cell lines $^{42}$. There are multiple mechanisms through which target cells alter the sensitivity and specificity of the response to corticosteroids. These take place at the levels of GR gene transcription, mRNA splicing, and mRNA translation, as well as through post-translational modifications and the inherent functional activity of the expressed isoform monomer(s) or dimer(s) on responsive genes. N-terminal domain of GR substantially contributes to this regulatory diversity ${ }^{42}$. The mineralocorticoid (MR), estrogen (ER), and progesterone $^{43}$ receptors also contain potential alternative translation initiation sites in their $\mathrm{N}$-terminal domains. Thus, like the GR gene, the genes encoding these receptors might produce $\mathrm{N}$-terminal isoforms ${ }^{42}$. Therefore, tissue-specific and regulated variable $\mathrm{N}$-terminal isoform production may be a general mechanism that defines target tissue sensitivity to steroid hormones, further adding to the complexity of their own signal transduction systems.

It has been shown that corticosteroids upregulate and downregulate up to 2000 genes that are involved in regulation of the immune response ${ }^{44}$.

If cortisol is able to act in genomic manner it is also responsible for nongenomic interaction. Physiochemical interactions occur in-between the cell's membrane and corticosteriods inducing very rapid, nonspecific, nongenomic effect ${ }^{45}$. For example during an acute stress the loss in interaction with hypothalamic synaptosomes may partly explain the loss in cortisol circadian rhythm ${ }^{46}$. Moreover corticosteroids act in this way about immediate catecholamine release from sympathetic cells, restoration of sympathetic modulation on heart and vessel ${ }^{47}$, sensitization to exogenous catecholamine in septic shock ${ }^{48,49}$. In addition through activation of endothelial nitric oxide synthase induces protective effects in ischemic brain injury ${ }^{50}$, and in ischemia/reperfusion injury ${ }^{51}$.

\section{MAIN ACTIONS OF CORTICOSTEROIDS IN SEPSIS}

Metabolic Effects

About metabolism of carbohydrates, corticosteroids play a major role in glucose metabolism stimulating liver gluconeogenesis and glycogenolysis also promoting the secretion of glucagon and adrenaline. They inhibit cellular uptake of glucose by inducing peripheral insulin resistance. All these actions have as consequence a rise in blood glucose concentration ${ }^{52}$. About proteins and fat metabolism, corticosteroids inhibit protein synthesis and activate proteinolysis in muscles, inhibit glucose uptake by adipocytes and activate lipolysis. Finally they are involved in bone and mineral metabolism, activating osteoclasts, inhibiting osteoblasts, decreasing intestinal calcium uptake and increasing calcium urinary secretion by decreasing its renal reabsorption ${ }^{1}$.

Immune Effects

Clinical relevance of corticosteroids in immune and inflammatory response is controversial; its affinity for immune cells is great. Its influence can realize through lymphocytes, natural killer (NK \#0), monocytes, macrophages, eosinophils, mast cells and basophils ${ }^{14}$. Corticosteroids administration is followed by a reduction of lymphocytes, which result in a passage of cells from blood to lymphoid organ. The opposite is true for granulocytes. To the reduction of inflammatory reaction contribute the lowering of chemokines and subsequently of neutrophil migration. Macrophage secretion is inhibited by the production of migration inhibitory factor [53], while eosinophils apoptosis is stimulated ${ }^{54}$.

Corticosteroids are involved in the immune response by inhibiting the production of IL-12 by macrophages and monocytes and influencing lymphocytes differentiations in favour of Th2 cells. All that would result in a rise of IL-4 and IL-13 secretion (which is normally inhibited by IL-12) and suppression of cellular immunity ${ }^{14}$. In patients with sepsis hydrocortisone does not suppress IL-12 secretion, an effect that resulted from hydrocortisone induced inhibition of pro-inflammatory state $^{55}$ (Figure 3).

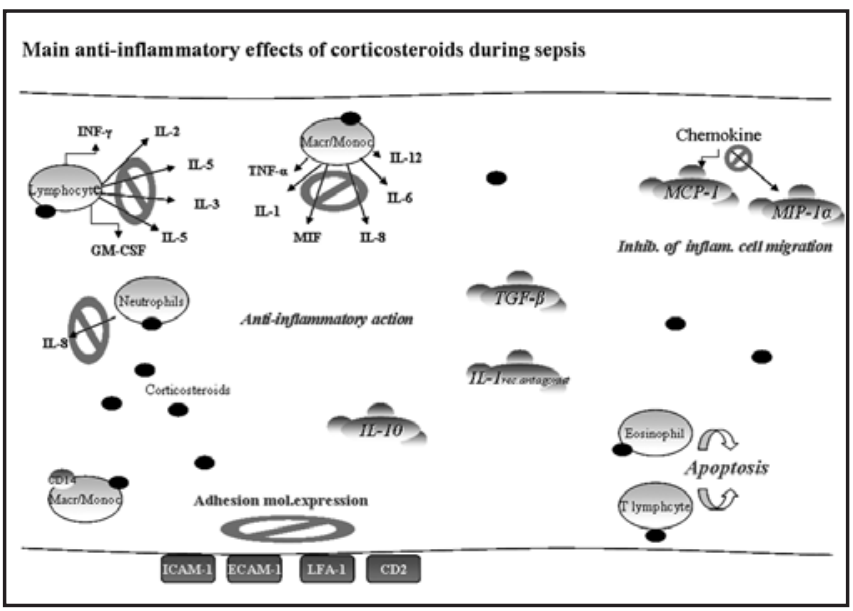

Figure 3 
Corticosteriods modulate the inflammatory response also acting on the cellular level by the inhibition of proinflammatory cytokines (IL-1, IL-2, IL-3, IL-6, interferon- $\gamma$, TNF- $\alpha$ ), chemochine, eicosanoids, bradykinins and inhibitory factor ${ }^{3,21,53}$. This is possible by interaction of corticosteroid complex and DNA where it can active and inhibit transcriptional factors ${ }^{45}$.

In the last decade, in septic shock patients, corticosteroids have been shown to attenuate the inflammatory response without causing immune suppression. Indeed, intravenous hydrocortisone decreased core temperature, heart rate and plasma levels of $\mathrm{PLA}_{2}$ and $C$-reactive protein ${ }^{56}$. Its decreased circulating levels of IL-6 and IL-8, prevented the endothelial activation and also decreased circulating levels of TNF soluble receptors I and II, and IL-10. Hydrocortisone is also able to favour the expansion of peripheral blood-derived CD56 (+) cells, allowing the differentiation of NK cells ${ }^{57}$.

\section{Cardiovascular Effects}

Corticosteroids regulate vascular reactivity to vasoconstrictors. Physiological concentrations of corticosteroids play a key role in maintaining an appropriate vascular reactivity to vasoconstrictors, hence the normal blood pressure. Multiple mechanisms are involved in corticosteroid-mediated vascular responses. It is known that chronic excess in corticosteroids induces hypertension, whereas Al induces hypotension. Corticosteroids act on vascular endothelial cells and inhibit the release of endothelial vasodilators such as $\mathrm{NO}$ and PGI2 by downregulating enzyme expression and activity. In vascular smooth muscle cells, corticosteroids enhance agonist-mediated pharmacomechanical coupling by increasing $\mathrm{Ca}^{++}$mobilization and $\mathrm{Ca}^{++}$sensitivity of myofilament. The corticosteroid-induced vascular changes occur within minutes and thus are unlikely dependant on genomic interaction. The precise mechanism of corticosteroids induced changes in the endothelium and vascular smooth muscle cells are not clear at present.

Administration of hydrocortisone simultaneously or just before infusion of lipopolysaccharide prevents vascular non responsiveness to noradrenaline in healthy subjects, as well as hypotension, rise of both heart rate and plasma adrenaline levels. In septic shock, Al was associated with a marked hyporesponsiveness to noradrenaline, which was fully reversed $1 \mathrm{~h}$ after $50 \mathrm{mg}$ of intravenous hydrocortisone ${ }^{48}$.
Corticosteroids regulate response to noradrenaline and angiotensine II. The mechanism of action may be partially explained by iNOS pathways inhibition. Another study confirm ability of the corticosteroid to reverse vessels insensitivity within $1 \mathrm{~h}$ without relationship with renin-angiotensin system or nitric oxide pathway ${ }^{49}$. Several placebo-controlled randomized studies emphasize the cardiovascular effects of low dose of corticosteroids (200-300 mg/day) for a prolonged period ${ }^{17,55,58-61}$. Hydrocortisone was associated with increased vascular resistance with little effects on cardiac index and pulmonary hemodynamic. It may be possible that the very early hemodynamic effects are nongenomic, whereas subsequent ones are partially due to iNOS inhibition ${ }^{55}$.

These trials also showed that use of corticosteroids reduces duration of shock and time of varopressor weaning. The hemodynamic effect was confirmed by a phase III trial, that also demonstered survival benefit from a 7-day treatment with $50 \mathrm{mg}$ of hydrocortisone every $6 \mathrm{hrs}$ and $50 \mu \mathrm{g}$ of fludrocortisone per os daily ${ }^{30}$. The beneficial effect of corticosteroids is more pronounced in non responders to ACTH. In a more recent study, infusion of $50-\mathrm{mg}$ bolus of hydrocortisone followed by a continuous infusion of $0.18 \mathrm{mg} / \mathrm{kg} / \mathrm{hr}$ determined in 41 hyperdynamic septic shock patients, was associated with a dramatic reduction of vasopressor support (53 hrs vs. $120 \mathrm{hrs}$ ) ad duration of shock and of proinflammatory cytokines. In this study the hemodynamic effects but not the immune effects of hydrocortisone were related to the adrenal status ${ }^{62}$.

\section{Survival Effects}

Data extracted from all more important trials (Table 1 ), shows mortality rate in control group and in treated group not significantly different. But subgroup analysis on trials with long courses ( $\geq 5$ days) of low dose corticosteroids $(\leq 300 \mathrm{mg}$ hydrocortisone or equivalent) showed a significant reduction in mortality rate in favour of corticosteroids, at 28 days and at ICU and hospital discharge ${ }^{62}$.

\section{Adverse Events}

In a recent meta-analysis of corticosteroid treatment during severe sepsis and septic shock there were no evidence for an increased risk of gastroduodenal bleeding (10 trials, $\mathrm{n}=1321 ; 1.16,0.82$ to $1.65, \mathrm{p}=$ 0.40 ), superinfection (12 trials, $n=1705 ; 0.93,0.73$ to $1.18, p=0.54$ ) or hyperglycemia (6 trials, $n=608$; 
Table 1 - Corticosteroid Trials in Severe Sepsis and Septic Shock Patients

\begin{tabular}{|c|c|c|c|}
\hline Reference & Population & Dose of Cortisone vs Placebo & Results \\
\hline Bollaert et al. (1998) & Septic shock (41) & $\begin{array}{l}100 \mathrm{mg} \times 3 \text { for } 5 \text { days of } \\
\text { hydrocortisone }\end{array}$ & $\begin{array}{l}\text { Reduction of mortality and } \\
\text { shock reversal time }\end{array}$ \\
\hline Briegel et al. (1999) & Septic shock (40) & $\begin{array}{l}100 \mathrm{mg}+0.18 \mathrm{mg} / \mathrm{kg} / \mathrm{hr} \text { of } \\
\text { hydrocortisone }\end{array}$ & $\begin{array}{l}\text { Reduction of time of } \\
\text { vasopressor infusion }\end{array}$ \\
\hline Chawla et al. (1999) & Septic shock (44) & $\begin{array}{l}100 \mathrm{mg} \times 4 \text { for } 72 \mathrm{hr} \text { of } \\
\text { hydrocortisone }\end{array}$ & $\begin{array}{l}\text { Reduction of shock reversal } \\
\text { time and vasopressor infusion }\end{array}$ \\
\hline Annane et al. (2002) & Septic shock (300) & $\begin{array}{l}50 \mathrm{mg} \times 6 \text { of hydrocortisone }+ \\
\text { fludrocortisone } 50 \mu \mathrm{g} \text { for } 7 \text { days }\end{array}$ & $\begin{array}{l}\text { Reduction of mortality and } \\
\text { relative adrenal insufficiency }\end{array}$ \\
\hline Yildiz et al. $(2002)^{63}$ & Severe sepsis (40) & $\begin{array}{l}\text { Physiological dose of } \\
\text { prednisolone for } 10 \text { days }\end{array}$ & Reduction of mortality \\
\hline Confalonieri et al. (2004) ${ }^{64}$ & Severe sepsis (46) & $\begin{array}{l}200 \mathrm{mg}+10 \mathrm{mg} / \mathrm{hr} \text { of } \\
\text { hydrocortisone }\end{array}$ & $\begin{array}{l}\text { Reduction of mortality and } \\
\text { delayed of septic shock }\end{array}$ \\
\hline Oppert et al (2005) & Septic shock (41) & $\begin{array}{l}50 \mathrm{mg}+0.18 \mathrm{mg} / \mathrm{kg} / \mathrm{hr} \text { of } \\
\text { hydrocortisone }\end{array}$ & $\begin{array}{l}\text { Reduction of shock reversal } \\
\text { time }\end{array}$ \\
\hline Tandan et al $(2005)^{65}$ & Septic shock (28) & Low doses of hydrocortisone & Reduction of mortality \\
\hline
\end{tabular}

$1.22,0.84$ to $1.78, p=0.30)^{62}$. Only one trial reported a rise in serum sodium concentration ( $>155 \mathrm{mmol} / \mathrm{L}$ ) in $6 / 20(30 \%)$ Patients in the treated group and in $1 / 20(5 \%)$ in the placebo group ${ }^{60}$.

\section{CONCLUSION AND RECOMMENDATIONS FOR CLINICAL PRACTICE}

During sepsis, hemodynamic instability and perpetuation of inflammatory state may result from Al. Thus, an ACTH test should be performed as soon as possible to identify non overt Al (Figure 4). It should be immediately followed by a replacement therapy with iv bolus of $50 \mathrm{mg}$ of hydrocortisone every 6 hours combined to $50 \mu \mathrm{g}$ of fludrocortisone once daily. When the results of the ACTH test are available, treatment should be continued for 7 days in the non responders to ACTH and withdraw in the responders. Whether responders to ACTH with high baseline cortisol levels

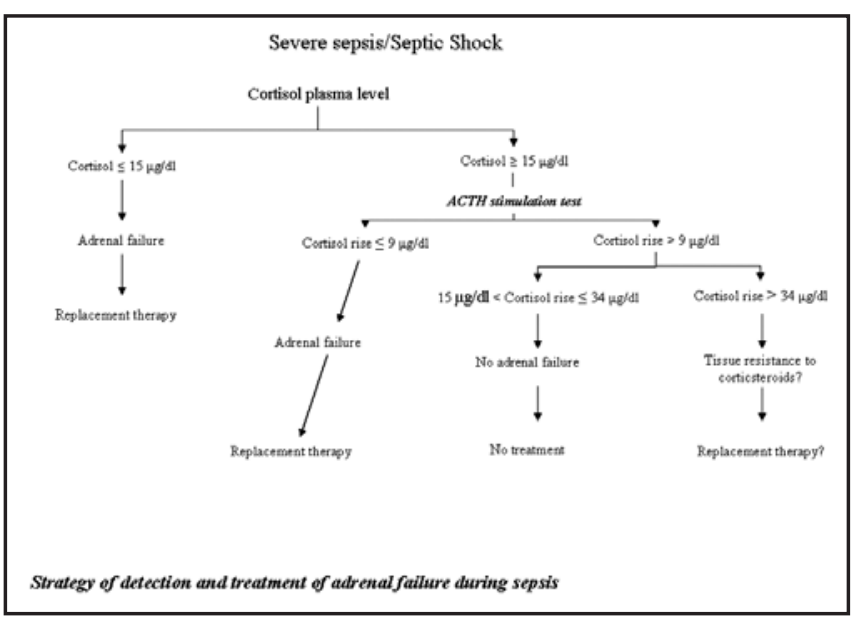

Figure 4
(> $34 \mu \mathrm{g} / \mathrm{dL}$ ) have tissue resistance to cortisol and also should receive exogenous hormones remains to be evaluated in clinical trials.

\section{REFERENCES}

01. Orth DN, De Bold CR - Williams Textbook of Endocrinology; em: Wilson JD, Foster DW - Williams Textbook of Endocrinology. Philadelphia: W.B. Saunders Company, 1992;489-531.

02. Chrousos G - The hypothalamic-pituitary-adrenal axis and immune-mediated inflammation. N Engl J Med, 1995;332:1351-1362.

03. Cavaillon $\mathrm{J}$ - Action of glucocorticoids in the inflammatory cascade. Reanim Urgences, 2000;9: 605-612.

04. Tsigos C, Chrousos G - Hypothalamic-pituitary-adrenal axis, neuroendocrine factors and stress. J Psychosom Res, 2002;53:865-871.

05. Marik PE, Zaloga GP - Adrenal insufficiency in the critically ill: a new look at an old problem. Chest, 2002;122:1784-1796.

06. Kino T, Chrousos G - Glucocorticoid and mineralocorticoid receptors and associated diseases. Essays Biochem, 2004;40:137-155.

07. Kino T, de Martino MU, Charmandari E et al - Tissue glucocorticoid resistance/hypersensitivity syndrome. J Steroid Biochem Mol Biol, 2003;85:457-467.

08. Chrousos GP, Charmandari E, Kino T - Glucocorticoid action networks-an introduction to systems biology. J Clin Endocrinol Metab, 2004;89:563-564.

09. Kino T, Mirani M, Alesci S et al - AIDS-related lipodystrophy/insuline resistance syndrome. Horm Metab Res, 2003;35:129-136.

10. Kino $T$, Gragerov A, Slobodskaya $O$ et al - Human immunodeficiency virus type 1 (HIV-1) accessory protein $\mathrm{Vpr}$ induces transcription of the HIV-1 and glucocorticoid-responsive promoters by binding directly to p300/CBP coactivators. J Virol, 2002;76:9724-9734.

11. Lamberts SW, Bruining HA, de Jong FH - Corticosteroid therapy in severe illness. N Engl J Med, 1997; 337:1285-1292.

12. Beishuizen A, Thijs LG, Vermes I - Patterns of corticosteroid--binding globulin and the free cortisol index during sepsic shock and multitrauma. Intensive Care Med, 2001;27:1584-1591.

13. Franchimont D, Martens $\mathrm{H}$, Hagelstein MT et al - Tumor necrosis factor alpha decreases, and interleukin-10 increases, the sensitivity of human monocytes to dexamethasone: potential regulation of the glucocorticoid receptor. J Clin Endocrinol Metab, 1999;84:2834-2839.

14. Chrousos G - The stress response and immune function: clinical implications. The 1999 Novera H. Spector Lecture, Ann N Y Acad Sci, 2000;917:38-67.

15. McKee JI, Finlay WE - Cortisol replacement in severely stressed patients. Lancet, 1983;1:(8322):484.

16. Cooper MS, Stewart PM - Corticosteroid insufficiency in acutely ill patients. N Engl J Med, 2003;348: 727-734.

17. Annane D, Sebille V, Charpentier C et al - Effect of treatment with low 
doses of hydrocortisone and fludrocortisone on mortality in patients with septic shock. JAMA, 2002;288: 862-871.

18. Rothwell PM, Lawler PG - Prediction of outcome in intensive care patients using endocrine parameters. Crit Care Med, 1995;23:78-83.

19. Rothwell PM, Udwadia ZF, Lawler PG - Cortisol response to corticotropin and survival in septic shock. Lancet, 1991;337:582-583.

20. Annane D, Sebille V, Troche G et al - A 3-level prognostic classification in septic shock based on cortisol levels and cortisol response to corticotropin. JAMA, 2000;283:1038-1045.

21. Soni A, Pepper GM, Wyrwinski PM et al - Adrenal insufficiency occurring during septic shock: incidence, outcome, and relationship to peripheral cytokine levels. Am J Med, 1995;98:266-271.

22. Sharshar T, Annane D, de la Grandmaison G et al - The neuropathology of septic shock. Brain Pathol, 2004;14:21-33.

23. Melby JC - Drug spotlight program: systemic corticosteroid therapy: pharmacology and endocrinologic considerations. Ann Intern Med, 1974;81:505-512.

24. Hall GM, Lacoumenta S, Hart GR et al - Site of action of fentanyl in inhibiting the pituitary-adrenal response to surgery in man. $\mathrm{Br} \mathrm{J}$ Anaesth, 1990;65:251-253.

25. Absalom A, Pledger D, Kong A - Adrenocortical function in critically ill patients $24 \mathrm{~h}$ after a single dose of etomidate. Anaesthesia, 1999;54:861-867

26. Annane D - ICU physicians should abandon the use of etomidate! Intensive Care Med, 2005; 31:325-326.

27. Abel SM, Back DJ - Cortisol metabolism in vitro - III. Inhibition of microsomal 6 beta-hydroxylase and cytosolic 4-ene-reductase. J Steroid Biochem Mol Biol, 1993;46:827-832.

28. Ushiama $\mathrm{H}$, Echizen $\mathrm{H}$, Nachi $\mathrm{S}$ et al - Dose-dependent inhibition of CYP3A activity by clarithromycin during Helicobacter pylori eradication therapy assessed by changes in plasma lansoprazole levels and partial cortisol clearance to 6 beta-hydroxycortisol. Clin Pharmacol Ther, 2002;72:33-43.

29. Oelkers W - Adrenal insufficiency. N Engl J Med, 1996;335:1206-1212.

30. Bernier J, Jobin N, Emptoz-Bonneton A et al - Decreased corticosteroidbinding globulin in burn patients: Relationship with interleukin-6 and fat in nutritional support. Crit Care Med, 1998;26:452-460.

31. Cordido F, Alvarez-Castro P, Isidro ML et al - Comparison between insulin tolerance test, growth hormone $(\mathrm{GH})$-releasing hormone $(\mathrm{GHRH})$, GHRH plus acipimox and GHRH plus $\mathrm{GH}$-releasing peptide-6 for the diagnosis of adult $\mathrm{GH}$ deficiency in normal subjets, obese and hypopituitary patients. Eur J Endocrinol, 2003;149:117-122.

32. Pfeifer M, Kanc K, Verhovec R et al - Reproducibility of the (ITT) for assessment of $\mathrm{GH}$ and cortisol responses in normal and hypopituitaric adult man. Clin Endocrinol (Oxf), 2001;54:17-22.

33. Nye E, Grice JE, Hockings $\mathrm{Gl}$ et al - The insulin hypoglycemia test: hypoglycemic criteria and reproducibility. J Neuroendocrinol, 2001;13:524-530.

34. Berneis K, Staub JJ, Gessler A et al - Combined stimulation pf adrenocorticotropin and compound-S by single dose metyrapone test as an outpatient procedure to assess hypotalamic-pituitary-adrenal function. J Clin Endocrinol Metab, 2002;87:5470-5475.

35. Schmidt IL, Lahner $\mathrm{H}$, Mann $\mathrm{K}$ et al - Diagnosis of adrenal insufficiency: evaluation of the corticotropin-releasing hormone test and basal serum cortisol in comparison to the insuline tolerance test in patients with hypotalamic-pituitary-adrenal disease. J Clin Endocrinol Metab, 2003;88:4193-4198.

36. Doe R, Fernandez R, Seal US - Measurement of corticosteroid-binding globulin in man. J Clin Endocrinol Metab, 1964;24:1029-1039.

37. Graybeal ML, Fang VS - Physiological dosimg of exogenous ACTH Acta Endocrinol, 1985;108:401-406.

38. Dickstein G, Shechner C, Nicholson WE et al - Adrenocorticotropin stimulation test: effect of basal cortisol level, time of day and suggested new sensitive low dose test. J Clin Endocrinol Metab, 1991;72:773-778.

39. Bamberger CM, Bamberger AM, de Castro M et al - Glucocorticoid receptor beta, a potential endogenous inhibitor fo glucocorticoid action in humans. J Clin Invest, 1995;95:2435-2441.

40. Charmandari E, Chrousos GP, Ichijo T et al - The human glucocorticoid receptor (hGR) beta-isoform suppresses the transcriptional activity of HGRalpha by interfering with formation of active coactivator complexes. Mol Endocrinol, 2005;19:52-64.

41. Yudt MR, Jewell CM, Bienstock RJ et al - Molecular origins for the dominant negative function of human glucocorticoid receptor-beta. Mol Cell
Biol, 2003;23:4319-4330.

42. Lu NZ, Cidlowski JA - Translational regulatory mechanisms generate $\mathrm{N}$-terminal glucocorticoid receptor isoforms with unique transcriptional target gene. Mol Cell, 2005;18:331-342.

43. Bernard GR, Luce JM, Sprung CL et al - High dose corticosteroids in patients with the adult respiratory distress syndrome. N Engl J Med, 1987;317:1565-1570.

44. Galon J, Franchimont D, Hiroi N et al - Gene profiling reveals unknown enhancing and suppressive actions of glucocorticoids on immune cells. FASEB J, 2002;16:61-71.

45. Almawi WI - Molecular mechanisms of glucocorticoids effects. Mod Asp Immunobiol, 2001;2:78-82.

46. Edwardson JA, Bennett GW - Modulation of corticotropin-releasing factor release from hypotalamic synaptosome. Nature, 1974;251:425-427.

47. Orlikowsky D, Castel M, Annane D - Acute effect of a single intravenous bolus of $50 \mathrm{mg}$ hydrocortisone on cardiovascular autonomic modulation in septic shock. Crit Care Med, 2003; 31:(Suppl):A124.

48. Annane D, Bellissant E, Sebille V et al - Impaired pressor sensitivity to noradrenaline in septic shock patients with and without impaired adrenal function reserve. Br J Clin Pharmacol, 1998;46:589-597.

49. Bellissant E, Annane D - Effect of hydrocortisone on phenylephrine mean arterial pressure dose-response relationship in septic shock. Clin Pharmacol Ther, 2000;68:293-303.

50. Limbourg FP, Huang Z, Plumier JC et al - Rapid nontranscriptional activation of endothelial nitric oxide synthase mediates increased cerebral blood flow and stroke protection by corticosteroids. J Clin Invest, 2002;110:1729-1738.

51. Hafezi-Moghadam A, Simoncini T, Yang Z et al - Acute cardiovascular protective effects of corticosteroids are mediated by non-transcriptional activation of endothelial nitric oxide synthase Nat Med, 2002;8:473479.

52. Pilkis SJ, Granner DK - Molecular physiology of the regulation of the hepatic gluconeogenesis and glycolysis. Annu Rev Physiol, 1992;54:885909.

53. Beishuizen A, Thijs LG, Haanen C et al - Macrophage migration inhibitory factor and hypothalamo-pituitary-adrenal function during critical illness. $\mathrm{J}$ Clin Endocrinol Metab, 2001;86:2811-2816.

54. Beishuizen A, Vermes I, Hylkema BS et al - Relative eosinophilia and functional adrenal insufficiency in critically ill patients Lancet, 1999;353:1675-1676.

55. Keh D, Boehnke T, Weber-Cartens S et al - Immunologic and hemodynamic effects of "low-dose" hydrocortisone in septic shock: a doubleblind, randomized, placebo-controlled, crossover study. Am J Respir Crit Care Med, 2003;167:512-520.

56. Briegel J, Kellermann W, Forst $\mathrm{H}$ et al - Low-dose hydrocortisone infusion attenuates the systemic inflammatory response syndrome. The Phospholipase A2 Study Group. Clin Investig, 1994;72:782-787.

57. Perez SA, Mahaira LG, Demirtzoglou FJ et al - A potential role for hydrocortisone in the positive regulation of IL-15-activated NK cell proliferation and survival. Blood, 2005;106:158-166.

58. Oppert M, Schindler R, Husung $\mathrm{C}$ et al - Low-dose hydrocortisone improves shock reversal and reduces cytokine on early hyperdinamic septic shock. Crit Care Med, 2005;33:2457-2464.

59. Bollaert PE, Charpentier C, Levy B et al - Reversal of late septic shock with supraphysiologic doses of hydrocortisone. Crit Care Med, 1998;26:645-650.

60. Briegel J, Forst $\mathrm{H}$, Haller $\mathrm{M}$ et al - Stress dose of hydrocortisone reverse hyperdynamic septic shock: a prospective, randomized, double-blind, single-center study. Crit Care Med, 1999;27:723-732.

61. Chawla K, Tessler S - Hydrocortisone reverses refractory septic shock. Crit Care Med, 1999;27:A33

62. Annane D, Bellissant E, Bollaert PE et al - Corticosteroids for treating severe sepsis and septic shock: a systematic review and meta-analysis. BMJ, 2004;329:480-

63. Yildiz O, Doganay M, Aygen B et al - Physiologic-dose steroid therapy in sepsis. Crit Care, 2002; 6:251-259.

64. Confalonieri M, Urbino R, Potena A et al - Hydrocortison infusion for severe community-acquired pneumonia: a preliminary randomized study. Am J Respir Crit Care Med, 2005;171:242-248.

65. Tandan SM, Gupta N - Low dose steroids and adrenocortical insufficiency in septic shock: a double-blind randomised trial from India. Am J Respir Crit Care Med, 2005;[A24][Poster:326] 